\title{
Interannual variability in an atlas of trace element signatures for determining population connectivity
}

\author{
Seth H. Miller ${ }^{1, *}$, Steven G. Morgan ${ }^{1,2}$, J. Wilson White ${ }^{3}$, Peter G. Green ${ }^{4}$ \\ ${ }^{1}$ Bodega Marine Laboratory, University of California Davis, Bodega Bay, California 94923, USA \\ ${ }^{2}$ Department of Environmental Science and Policy and ${ }^{4}$ Department of Civil and Environmental Engineering, \\ University of California Davis, Davis, California 95616, USA
}

${ }^{3}$ Department of Biology and Marine Biology, University of North Carolina Wilmington, Wilmington, North Carolina 28403, USA

\begin{abstract}
Natural trace element signatures have increasingly been used to track the dispersal of marine larvae, and these studies require an atlas of potential source populations with distinctive elemental signatures. To determine whether natal site atlases could be used repeatedly and to identify site characteristics that yield the best results, we built atlases in 5 consecutive years using embryos of the porcelain crab Petrolisthes cinctipes that were collected from 15 sites spanning $190 \mathrm{~km}$ of the open coast of northern California, USA. We analyzed the elemental composition of the embryos using a discriminant function optimization procedure to determine the suite of elements that resulted in the best reclassification success for individual sites and groups of sites each year. No single element or group of elements succeeded in discriminating the origins of embryos every year, and the reclassification success of the atlas varied at all spatial scales among years. Average reclassification success at the site level ranged annually from 39.5 to $54.3 \%$ correct, and combining sites into 2 or 3 areas improved the overall reclassification success to 72.5 to $97.7 \%$ correct. Sites with (1) distinctive elemental compositions of rocks, (2) unusual habitats, (3) consistent freshwater input, (4) consistent anthropogenic inputs, or (5) complex local oceanography had the highest reclassification success (up to $86.7 \%$ correct), but interannual variation in runoff reduced the temporal stability of the atlas. To improve population connectivity estimates, future trace element studies should consider these 5 key characteristics when selecting sites and anticipate temporal variation in natal site signatures.
\end{abstract}

KEY WORDS: Larval dispersal · Trace element signatures · Population connectivity · Natal site atlas $\cdot$ Petrolisthes cinctipes

\section{INTRODUCTION}

Understanding how marine populations are connected is critically important for managing fisheries, marine protected areas, and the spread of invasive species as well as understanding the evolution of life in the sea. However, most benthic marine species have a 2-stage life history: relatively sedentary adults release hundreds to millions of minuscule larvae that develop for weeks to months in the water column before settling to adult populations. Determining where these larvae go is essential to understanding population connectivity but is technically challenging. Visually tracking individuals is impossible for all but the largest larvae and even then only briefly (Olson 1985, Carlon \& Olson 1993). Artificially tagging larvae is usually impractical because the mark must be distinctive, easily applied to millions of individuals, retained throughout larval development, invisible to predators, non-stressful to larvae, and effectively recovered from settled juveniles (but see Jones et al. 1999, Almany et al. 2007). Using naturally occurring 'tags' from the distinctive signatures of trace elements in water masses is more feasible 
(Thorrold et al. 2002). Elemental signatures are either transferred to larvae by their mothers or absorbed from the natal environment and retained throughout their pelagic development (Levin et al. 1993, Anastasia et al. 1998, DiBacco \& Levin 2000). Dispersal trajectories and the natal origins of larvae can be determined by matching the natal elemental signatures of settlers to the signature of the location where they hatched. To do this, researchers first create a natal site atlas using embryos (e.g. Carson et al. 2008) or outplanted larvae (e.g. Becker et al. 2005) and then collect settlers and match their trace elemental signatures to that atlas (Thorrold et al. 1998, Becker et al. 2007, Hobbs et al. 2007).

Previous research has shown that the success of a natural trace element study depends largely on how many sites are sampled for the natal atlas, the dispersal distances of larvae, and the distinctiveness of site signatures. Widely spaced sites can be easily distinguished, even among multiple years (Zacherl 2005), but closely spaced sites can be difficult to resolve, especially in open coast environments (Neubauer et al. 2010). Differentiating trace element signatures among closely spaced sites is important because many larvae likely disperse relatively short distances (Strathmann et al. 2002, Swearer et al. 2002, Morgan et al. 2009). Increasing the number of sites and focusing on areas that are an appropriate scale for the study organism will reduce the likelihood of settlers coming from locations beyond the study area, providing a fuller and more accurate representation of local connectivity without needing to assign settlers to unknown sites (White \& Ruttenberg 2007, White et al. 2008). Additionally, determining the temporal stability of natal site atlases is essential (Carson et al. 2010, Cook 2011). If trace element signatures are stable, then a natal atlas would only need to be created once, thereby reducing the effort and expense required to conduct population connectivity studies. Conversely, if local trace element signatures vary interannually, then developing an atlas only once would yield misleading results in subsequent years.

By closely examining the factors responsible for creating and maintaining trace element signatures, investigators can select distinctive sites for the natal atlas, even along a short stretch of coastline. Trace element signatures are influenced by a number of factors (Table 1), including geology (Preda \& Cox 2001, Peng et al. 2004), anthropogenic inputs (Flegal et al. 2005, Hurst \& Bruland 2008), and freshwater runoff (Borrego et al. 2004, Sanchez-Garcia et al. 2010). In addition, the configuration of the coastline along the western margins of continents affects the strength of coastal upwelling and the composition of trace elements in water masses, as is clearly evident in the distinctive trace element signatures of upwelled waters (Sanudo-Wilhelmy \& Flegal 1996, Lares et al. 2002, Chase et al. 2005). Upwelling is typically strong at headlands (upwelling centers), and it is weak in the lee of headlands where water is recirculated (Graham \& Largier 1997). Interannual and seasonal variation in upwelling and precipitation also affect the trace element composition of water masses, which reduces the stability of atlases of water masses. For example, runoff of trace elements and pollutants into coastal waters could be greater during wet years than in dry years, which would increase the anthropogenic signal in those water masses while proportionally decreasing the natural trace element signal in those waters. Thus, geology, freshwater runoff, upwelling, and anthropogenic inputs combine to create a complex and diverse trace element seascape, and understanding the spatial and temporal contribution of each feature can improve the interpretation and ultimately the success of trace element studies in any region.

The purpose of the present investigation was to characterize the interannual stability of natal trace element signatures among 15 closely spaced sites along $190 \mathrm{~km}$ of open coast in the upwelling region of

Table 1. Elements that have been shown to vary within a study region due to local factors

\begin{tabular}{|c|c|c|c|c|c|c|c|c|c|c|c|c|}
\hline \multirow{2}{*}{ Factor } & \multirow[b]{2}{*}{$\mathrm{Mg}$} & \multirow[b]{2}{*}{$\mathrm{V}$} & \multirow[b]{2}{*}{$\mathrm{Cr}$} & \multirow[b]{2}{*}{ Mn } & \multirow[b]{2}{*}{$\mathrm{Fe}$} & \multicolumn{2}{|c|}{ Element - } & \multirow[b]{2}{*}{$\mathrm{Zn}$} & \multirow[b]{2}{*}{ As } & \multirow[b]{2}{*}{$\mathrm{Sr}$} & \multirow[b]{2}{*}{$\mathrm{Cd}$} & \multirow[b]{2}{*}{$\mathrm{Pb}$} \\
\hline & & & & & & $\mathrm{Co}$ & $\mathrm{Cu}$ & & & & & \\
\hline Geology & & & & & & 8 & 8 & 8 & & & 8 & 8 \\
\hline Freshwater runoff & 9 & 9 & 9 & & 1 & 9 & $1,9,10$ & $1,9,10$ & 1,10 & 12 & 1 & 1,10 \\
\hline Upwelling & & & & 2 & 2 & & & & & & 6,11 & \\
\hline Human influences & & & & & & 4 & $3,4,5$ & 5 & & & 7 & $3,4,5$ \\
\hline
\end{tabular}

${ }^{1}$ Borrego et al. (2004); ${ }^{2}$ Chase et al. (2005); ${ }^{3}$ Flegal et al. (2005); ${ }^{4}$ Hurst \& Bruland (2008); ${ }^{5}$ Hwang et al. (2009); ${ }^{6}$ Lares et al. (2002); ${ }^{7}$ McKenzie et al. (2009); ${ }^{8}$ Peng et al. (2004); ${ }^{9}$ Preda \& Cox (2001); ${ }^{10}$ Sanchez-Garcia et al. (2010); ${ }^{11}$ SanudoWilhelmy \& Flegal (1996); ${ }^{12}$ Ziegler \& Whitledge (2011) 
northern California (Fig. 1) during 5 consecutive years (2006 to 2010). We also reviewed factors that could have contributed to generating spatial variation in these signatures. Distinctive trace element signatures were expected to occur in the study area due to strong upwelling between Point Arena and Bodega Head, freshwater runoff from the Russian River, and contaminated outflow from San Francisco Bay (Flegal et al. 2005, Connor et al. 2007). Furthermore, the elemental composition of rocks varies from Pleistocene-era terrace deposits of cobble to Miocene-era sandstone, shale, or mudstone, thus affecting the signatures of water masses along the coast (Wagner et al. 1991). We created a site atlas for the porcelain crab Petrolisthes cinctipes because crabs are excellent candidates for trace-element studies. Embryos are brooded externally and incorporate trace elements from substrates as well as surrounding waters, resulting in distinctive signatures (Anderson et al. 2006, Smalling et al. 2010).

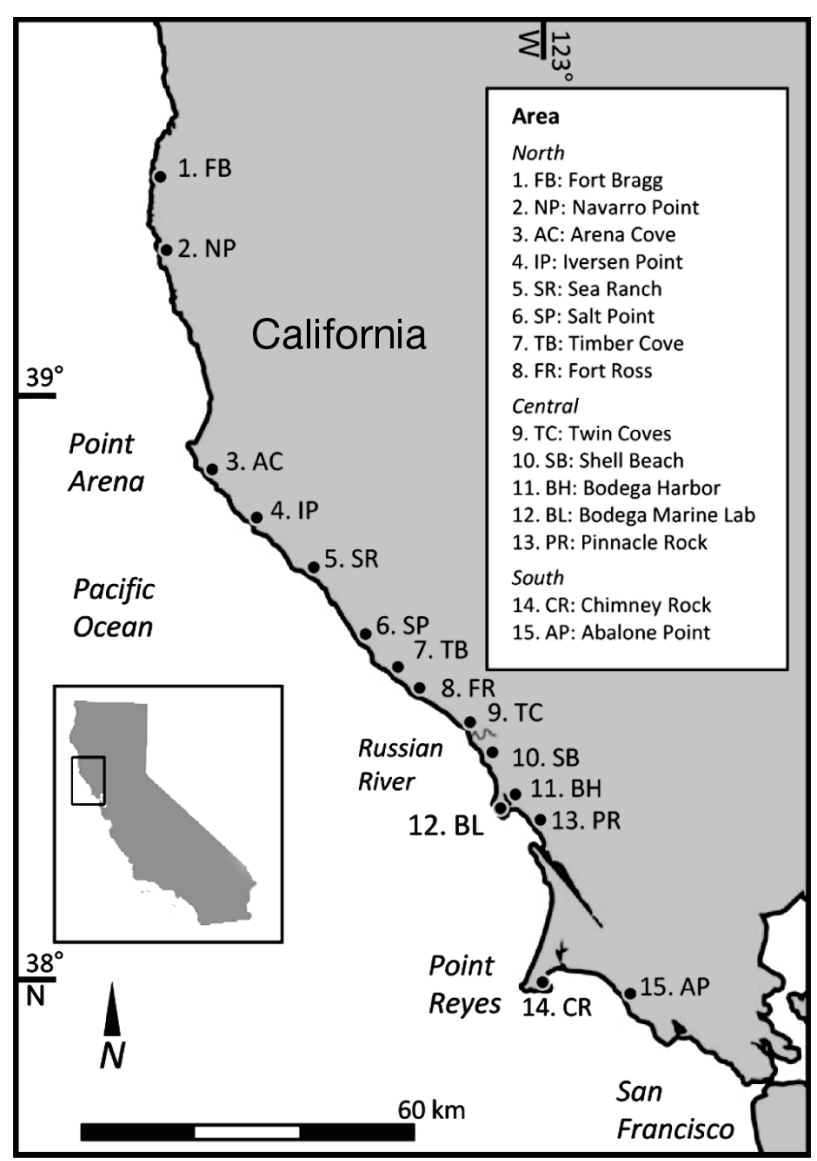

Fig. 1. Study region, depicting collection sites grouped into 3 areas relative to coastal features. The central and south areas also were combined into a southern region for comparison with the region north of the Russian River

\section{MATERIALS AND METHODS}

We collected 10 to 25 ovigerous Petrolisthes cinctipes during the peak reproductive season (April to May) at each of our field sites from Fort Bragg in Mendocino County to Abalone Point in Marin County (Fig. 1) and froze them individually in trace-element pure (Fisher) muriatic acid-washed vials. To determine embryo trace element signatures, we removed $\sim 10$ embryos from each crab, added $0.5 \mathrm{ml}$ of $2 \mathrm{~N}$ $\mathrm{NaOH}$ (Alfa Aesar, trace element grade) to each sample, and dissolved embryo soft tissues in an $80^{\circ} \mathrm{C}$ water bath for $3 \mathrm{~d}$. Samples were processed with a base because an acid would have dissolved the calcified structures as well as the soft tissues. Trace element signatures were investigated only in soft tissues because larval crustaceans can retain trace elements in their soft tissues through several molts (Anastasia et al. 1998), and trace element signatures in embryo soft tissues are similar to soft tissue signatures of firststage zoea (Miller 2011). Sample solutions were transferred to $50 \mathrm{ml}$ acid-washed centrifuge tubes and diluted to $40 \mathrm{ml}$ volume using Milli-Q ultrapure water.

The trace element solutions from dissolved embryos were analyzed using an Agilent 7500i inductively coupled plasma mass spectrometer (ICP-MS). We analyzed 31 elements, of which 22 were used because they occurred at levels at least an order of magnitude higher than background blank measurements (Table 2). ICP-MS technical details, detection limits, and information on elemental standards can be found in Carson et al. (2008). To avoid contaminating samples and due to the low number of embryos brooded by our study species, measurements of embryo mass could not be used to standardize trace element data. Instead, we used raw element counts to create proportional scores for each sample (Aruga 1998).

Creating proportional scores was a multi-step process. First, ICP-MS counts for each element in blanks and samples were averaged, and any elements that were not at least an order of magnitude higher in the samples than in the blanks were eliminated from further consideration. Next, distributions of raw element counts were mapped along the latitudinal gradient in our study region to ensure that no elements varied by latitude (see Supplement 1 at www.intres.com/articles/suppl/m474p179_supp.pdf). Element counts then were summed across each sample to get a total count for all of the elements still in consideration in each sample. Individual element counts were then divided by the summed total to create a proportional score for each element in each sample. Proportional scores for each element were then averaged 
Table 2. The suite of elements yielding the optimal reclassification success using QDA for each grouping level (site, area, region) in each year. The total number of elements in each suite is displayed in the far right column

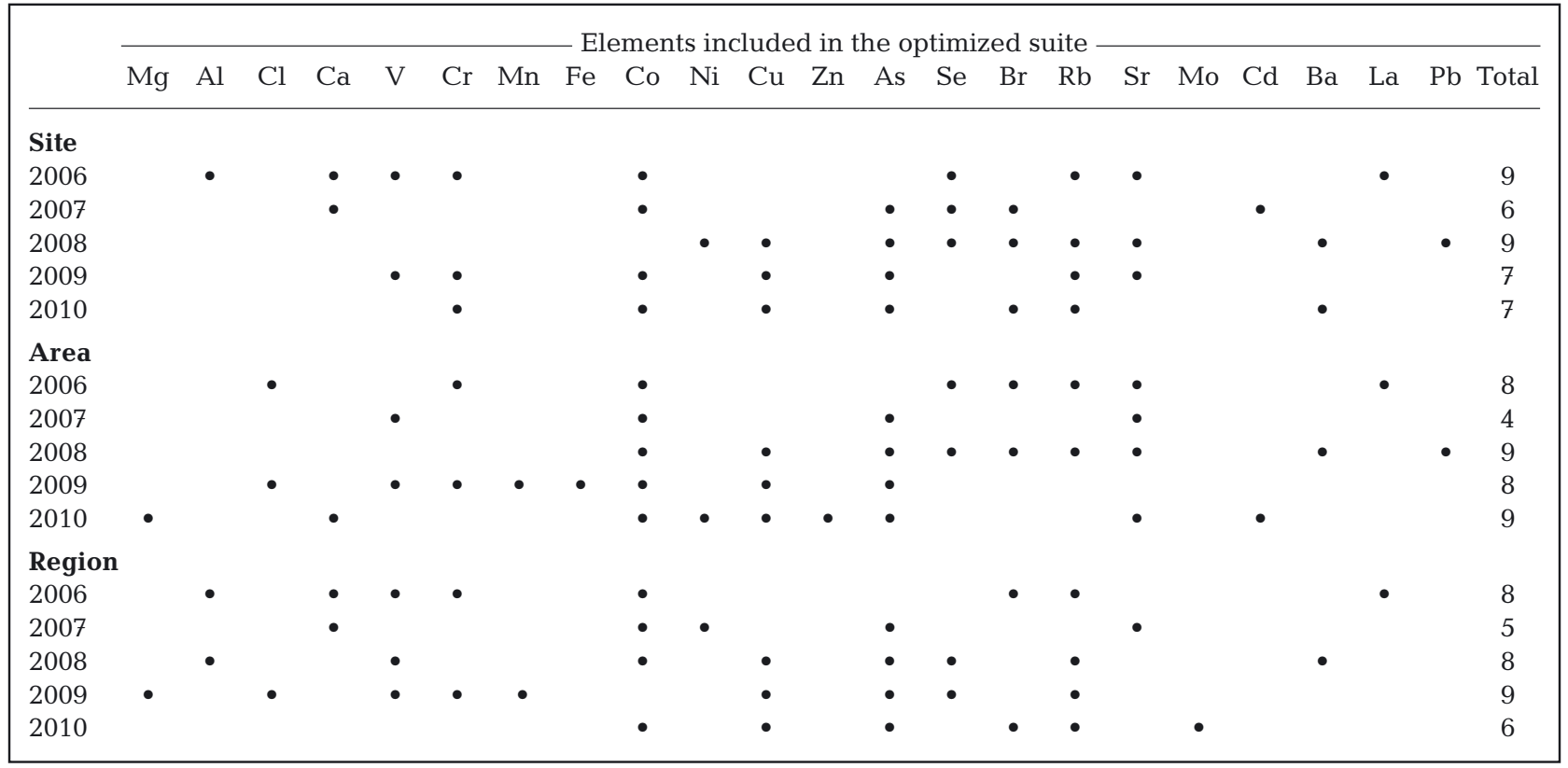

within sites, after which we compared site averages among sites and eliminated elements that had order of magnitude differences. We then recalculated the proportional scores and checked for order of magnitude differences again.

Checking for order of magnitude differences in elements among sites ensured that each elemental proportion was similarly scaled across sites and our proportional scores were comparable, accurately representing the true differences in elemental concentrations among sites. For example, if 2 sites had raw counts of 1 element that differed by an order of magnitude but very similar raw counts of 20 other elements, their proportional scores would be dramatically different, even though their actual trace element signatures would be virtually identical. By eliminating the elements with order of magnitude differences, we can be confident that the trace element signatures created using proportional scores are accurate representations of the actual trace element signatures present in the samples.

Proportional scores do not accurately compare the concentrations of trace elements among samples, but rather the relative proportions of each element among samples. The creation and use of proportional scores is novel for the field of ecology but is well established in many other fields of science, including chemistry (Aruga 1998, Fushimi et al. 2011), archaeology (Aruga et al. 1999, Kantarelou et al. 2011), environmental engineering (McKenzie et al. 2009), food and health sciences (Chiarenzelli \& Pominville 2008, Korhonova et al. 2009), and geology (Wu et al. 1990). These studies and others like them have successfully used proportional scores to create trace element signatures when the mass of material was unknown and then used those signatures to classify samples into groups as we do here.

We evaluated the reliability of the atlas of natal signatures in each year using leave-one-out ('jackknifed') reclassification success in discriminant analysis. The ICP-MS analysis and post-processing produced signatures of 9 to 20 elements for samples in each year. Using these, we sought to determine the optimal suite of elements that produced the highest reclassification success at 3 levels: site, area, and region (Fig. 1). Sites were combined into broader groups based on oceanography and hydrography. In our study region, outflow from San Francisco Bay is strongly anthropogenically influenced (Flegal et al. 2005, Hurst \& Bruland 2008) and travels a variable distance along the outer coast (Wing et al. 1995). We used features of the coast that approximately demarcated areas of differing San Francisco Bay influence (Point Reyes and Russian River) to combine sites into 3 areas or 2 regions (Fig. 1).

We calculated the jackknifed reclassification success using quadratic discriminant analysis (QDA) at each level of spatial grouping for every permutation of elements available in a given year (511 to 410210 elemental combinations). Element scores 
were fourth-root transformed to meet the assumptions of normality and equal variances. To reduce computation times, we preceded the optimization procedure for each year with univariate analysis of variance (ANOVA) tests for among-site differences in each element; elements that were similar ( $p>0.05)$ among sites were excluded from the optimization on the assumption that they would not provide good discrimination. In 2009 and 2010, nearly all elements differed among sites, and examining all permutations was not feasible due to the computational time required. The best success rates were obtained using 6 to 9 elements from 2006 to 2008, so for 2009 and 2010, we restricted our analysis to permutations over this range of combinations, i.e. 6, 7, 8, or 9 elements. QDAs were performed in Matlab 7.12 (Mathworks).

From the range of permutations considered in each year, we identified those that produced reclassification success rates in both the 95th percentile for overall value and 95th percentile for the mean groupwise success rate. This identified element combinations that had high success for all of the groups rather than just a few. The optimal suite of elements was chosen from within that subset as the suite that had the highest overall jackknife success rate. If no permutation of elements was in the 95th percentile for both categories, we took the permutation that had the highest overall jackknife success rate.

We also determined how well each year's optimized suite of elements reclassified embryo trace element signatures in other years, to simulate reusing a natal site atlas over multiple years. For each year, we used the optimized suite of elements and the natal signatures to classify the other year's data. Elements not analyzed in both years were omitted. Sites sampled in the test year but not during the training set year were omitted (but not the reverse) because it would be impossible to get a correct classification for those sites. When possible, QDA was used, but when covariance matrices were not singular positive definite, QDA was impossible, and linear discriminant analysis (LDA) was used.

Unlike LDA, QDA does not produce canonical variates (i.e. linear combinations of the original variables) that can be used to graphically display the results. Therefore, we used sliced average variance estimation (SAVE; Pardoe et al. 2007) to visualize the results of QDA classification in 2 dimensions. We also performed QDA on the optimized suites of elements to create plots for visualizing results, investigating the relationships among sites, and identifying the elements that composed distinctive trace element signatures.

\section{RESULTS}

The optimal suite of trace elements used for reclassifying samples varied among years and even among spatial groupings (site, area, or region) within years (Table 2). The optimal suite of elements contained from 4 to 9 elements, with 2006 and 2007 having on average the most and fewest elements, respectively. Though some elements belonged to the optimal suite for each level of spatial grouping in a given year, the optimal element suites for different groupings or years were never identical, and no single element belonged to all optimal element suites across all years. Vanadium $(\mathrm{V})$, cobalt $(\mathrm{Co})$, copper $(\mathrm{Cu})$, arsenic (As), and rubidium ( $\mathrm{Rb})$ were all used in more than half the optimized suites, whereas iron (Fe), zinc $(\mathrm{Zn})$, and molybdenum (Mo) were used in only 1 suite (Table 2).

The site-level embryo reclassification success ranged from 10.0 to $86.7 \%$ correct, with 2006 having the overall worst average reclassification success (39.5\% correct) and 2009 and 2010 having the overall best average success (54.3\% correct; Table 3). All success rates were greater than the $6.7 \%$ expected by the site-level null hypothesis that samples from the same site are unrelated, though in 2006 and 2007, some sites came close with only $10 \%$ correct (Table 4).

Table 3. Overall QDA reclassification successes for each year and group level. Columns to the right indicate sites, areas, or regions that had the highest ('best') and lowest ('worst') successes each year (see Fig. 1 for site abbreviations)

\begin{tabular}{|lccc|}
\hline \multicolumn{4}{c}{ Reclassification success (\%) } \\
& Overall & Best & Worst \\
\hline Site & & & \\
2006 & 39.5 & TC (61.1) & SB (10.0) \\
2007 & 42.6 & TC (77.8) & FR (10.0) \\
2008 & 53.9 & AC (80.0) & TB (20.0) \\
2009 & 54.3 & AC (86.6) & SB (33.3) \\
2010 & 54.3 & AC, BH (73.3) & PR, TB (35.7) \\
Area & & & \\
2006 & 72.5 & North (80.0) & Central (55.9) \\
2007 & 75.9 & North (76.9) & South (70.0) \\
2008 & 95.1 & North (96.1) & Central (93.3) \\
2009 & 94.1 & North (96.6) & South (89.7) \\
2010 & 79.9 & North (84.0) & Central (77.1) \\
Region & & & \\
2006 & 80.6 & North (80.6) & South (80.4) \\
2007 & 84.4 & North (85.9) & South (82.3) \\
2008 & 95.8 & South (96.9) & North (94.8) \\
2009 & 97.7 & North (98.3) & South (97.1) \\
2010 & 91.0 & North (91.0) & South (90.1) \\
\hline
\end{tabular}


The by-area reclassification successes were much higher than the by-site success rates. The individual by-area reclassification successes ranged from 55.9 to $96.6 \%$ correct, with 2006 again having the lowest overall average success $(72.5 \%)$ and 2008 having the overall best average success $(95.1 \%$; Table 3$)$. The figures showed a consistent relationship among areas throughout the present study and illustrated the among-year variability in the separation of samples and thus reclassification success (Fig. 2). Trace element signatures from the central and southern areas were the most dissimilar each year, and signatures from the northern area were intermediate, though spread among the areas varied.

Grouping sites into just 2 regions increased reclassification successes slightly over grouping sites into 3 areas, with individual regional successes ranging from 80.4 to $98.3 \%$ correct; 2006 had the lowest average success with $80.6 \%$ correct, and 2009 had the highest average success with $97.7 \%$ correct (Table 3 ). Embryos from the southern region had higher proportions of cobalt and copper, which can be associated with anthropogenic inputs and have been shown to be tracers of San Francisco Bay outflow (Fig. 3; Flegal et al. 1991, Hurst \& Bruland 2008).

Proportions of trace elements in embryos varied among sites every year (see Supplement 2 at www. int-res.com/articles/suppl/m474p179_supp.pdf), and optimized element suites from one year performed poorly when reclassifying samples from other years (Table 5), making it difficult to use one year's natal atlas to classify embryos from a different year. In fact, elemental concentrations also varied interannually at the area level (Fig. 2) and the region level (Fig. 3).

\section{DISCUSSION}

Our study showed persistent interannual variability not only in trace element signatures along the open coast but also in the reclassification successes of natal atlases. This reinforces the need to recreate a natal site atlas at least annually when conducting a study of population connectivity using trace elements in our region, suggesting that this could be the case in other study regions around the world. Importantly, our work also revealed that one-time exploratory tests of the utility of trace element signatures in a given area may be insufficient to determine the likelihood of success; tests conducted in a 'good' year (such as 2008 in our study) will likely be overly optimistic, while tests conducted in a 'bad' year (such as 2006 in our study) might lead researchers to incorrectly conclude that a study will not work in any year (Table 5). However, investigating the geologic, anthropogenic, hydrographic, and oceanographic features of a study region could provide information about the potential success of a trace element study and help researchers determine the spatial scale of sampling that will create the most useful natal site atlas.

Table 4. Percent correct reclassification successes for the 15 study sites each year and the factors that could be influencing those successes at each site. The site factors of runoff and upwelling are relative among sites within the region (e.g. all sites would have strong upwelling if compared to sites in southern California). Sites are arranged from north to south

\begin{tabular}{|c|c|c|c|c|c|c|c|c|}
\hline \multirow[t]{2}{*}{ Site } & \multicolumn{5}{|c|}{ - Classification success (\%) } & \multicolumn{3}{|c|}{ - Site factor - } \\
\hline & 2006 & 2007 & 2008 & 2009 & 2010 & Geology & Runoff & Upwelling \\
\hline Fort Bragg & 55.0 & 33.3 & 66.7 & 42.9 & 60.0 & PTD & Variable & Moderate \\
\hline Navarro Point & 50.0 & 44.4 & 50.0 & 66.7 & 53.3 & PTD & Low & Moderate \\
\hline Arena Cove & 50.0 & 70.0 & 80.0 & 86.7 & 73.3 & Sandstone, shale & Low & Strong \\
\hline Iversen Point & 45.0 & 30.0 & 55.6 & 46.7 & $1^{\mathrm{a}}$ & PTD & Low & Strong \\
\hline Sea Ranch & 36.8 & 30.0 & 66.7 & 64.3 & 38.7 & PTD & Low & Strong \\
\hline Salt Point & 28.6 & 50.0 & 40.0 & 71.4 & 64.3 & PTD & Low & Strong \\
\hline Timber Cove & 20.0 & 40.0 & 20.0 & 53.3 & 35.7 & PTD & Low & Strong \\
\hline Fort Ross & 40.0 & 10.0 & 50.0 & 53.3 & 50.0 & PTD & Low & Moderate \\
\hline Twin Coves & 61.1 & 77.8 & 66.7 & 64.3 & 58.3 & Sandstone melange & Variable & Moderate \\
\hline Shell Beach & 10.0 & 11.1 & 33.3 & 33.3 & 64.3 & PTD & Variable & Moderate \\
\hline Bodega Harbor & 25.0 & 66.7 & 70.0 & 46.7 & 73.3 & Sand & Variable & Weak \\
\hline Bodega Marine Laboratory & 40.0 & 60.0 & 50.0 & 40.0 & 60.0 & Granite & Low & Moderate \\
\hline Pinnacle Rock & 33.3 & 20.0 & 28.6 & 40.0 & 35.7 & Sand & Low & Weak \\
\hline Chimney Rock & 35.0 & 20.0 & 50.0 & 57.1 & 50.0 & Siltstone, mudstone & High & Weak \\
\hline Abalone Point & 60.0 & 60.0 & 70.0 & 53.3 & 42.9 & Sandstone, shale & High & Weak \\
\hline
\end{tabular}



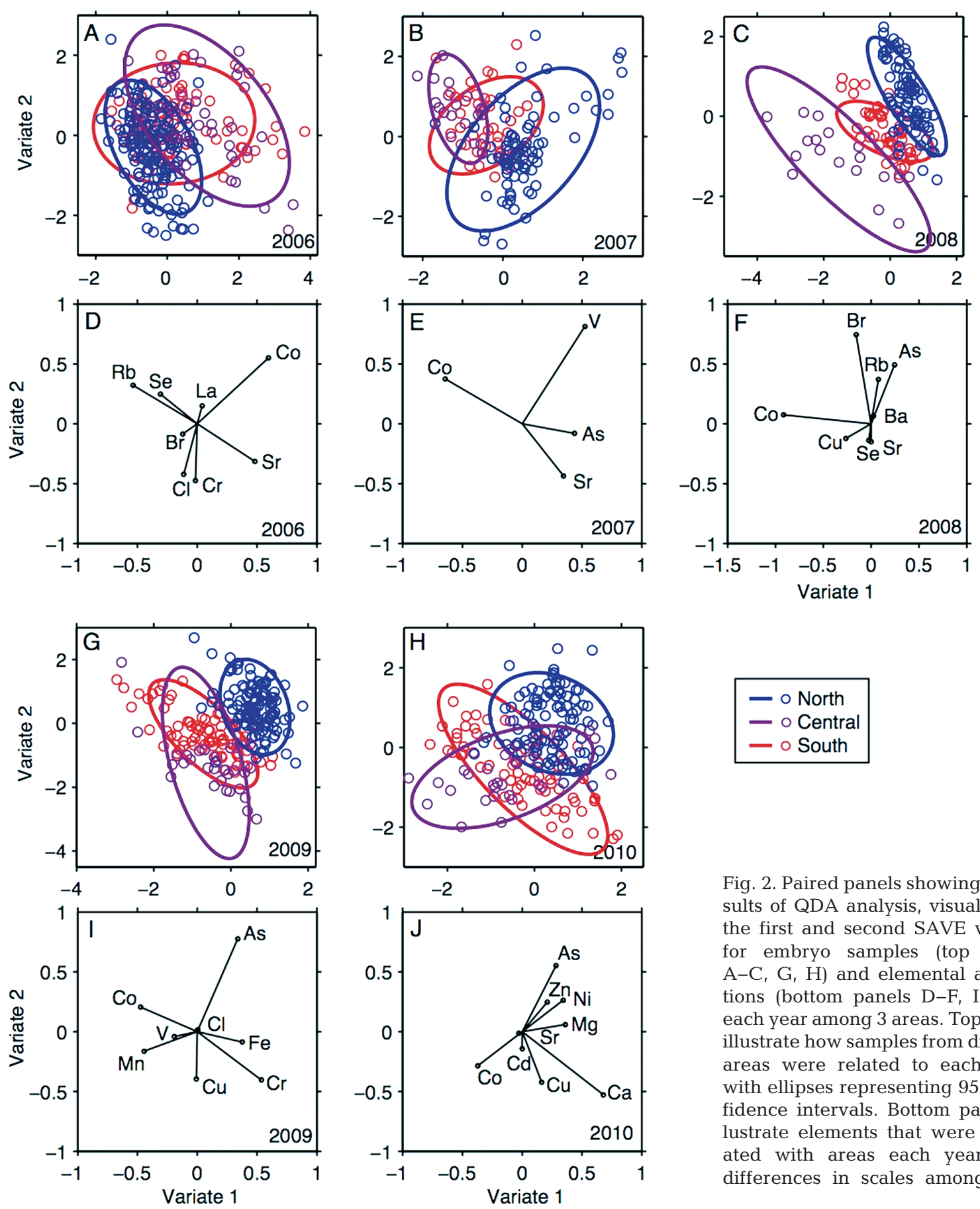

Fig. 2. Paired panels showing the results of QDA analysis, visualized as the first and second SAVE variates for embryo samples (top panels A-C, G, H) and elemental associations (bottom panels D-F, I, J) for each year among 3 areas. Top panels illustrate how samples from different areas were related to each other, with ellipses representing $95 \%$ confidence intervals. Bottom panels illustrate elements that were associated with areas each year. Note differences in scales among years

For example, analyzing data at the site level does not yield useful reclassification success in most studies, particularly when sites are closely spaced (e.g. Becker et al. 2005), so selecting distinctive, stable sites is important to increase the amount of information that could be gleaned from the study. However, this could be difficult, even in a multi-year study; some of our sites had consistently high reclassification success, some had consistently low success, and others had variable success among years (Table 4); additionally, important trace elements varied among and within sites across the $5 \mathrm{yr}$ of our study (Table 2, see Supplement 2 at www.int-res.com/articles/suppl/m474p179_ supp.pdf). Many sites also seemed to have at least 1 'bad' year when their reclassification success dropped far below those in other years, though these years varied among sites (Table 4). Thus, determining the sites that are most useful in an atlas is difficult, but re- 

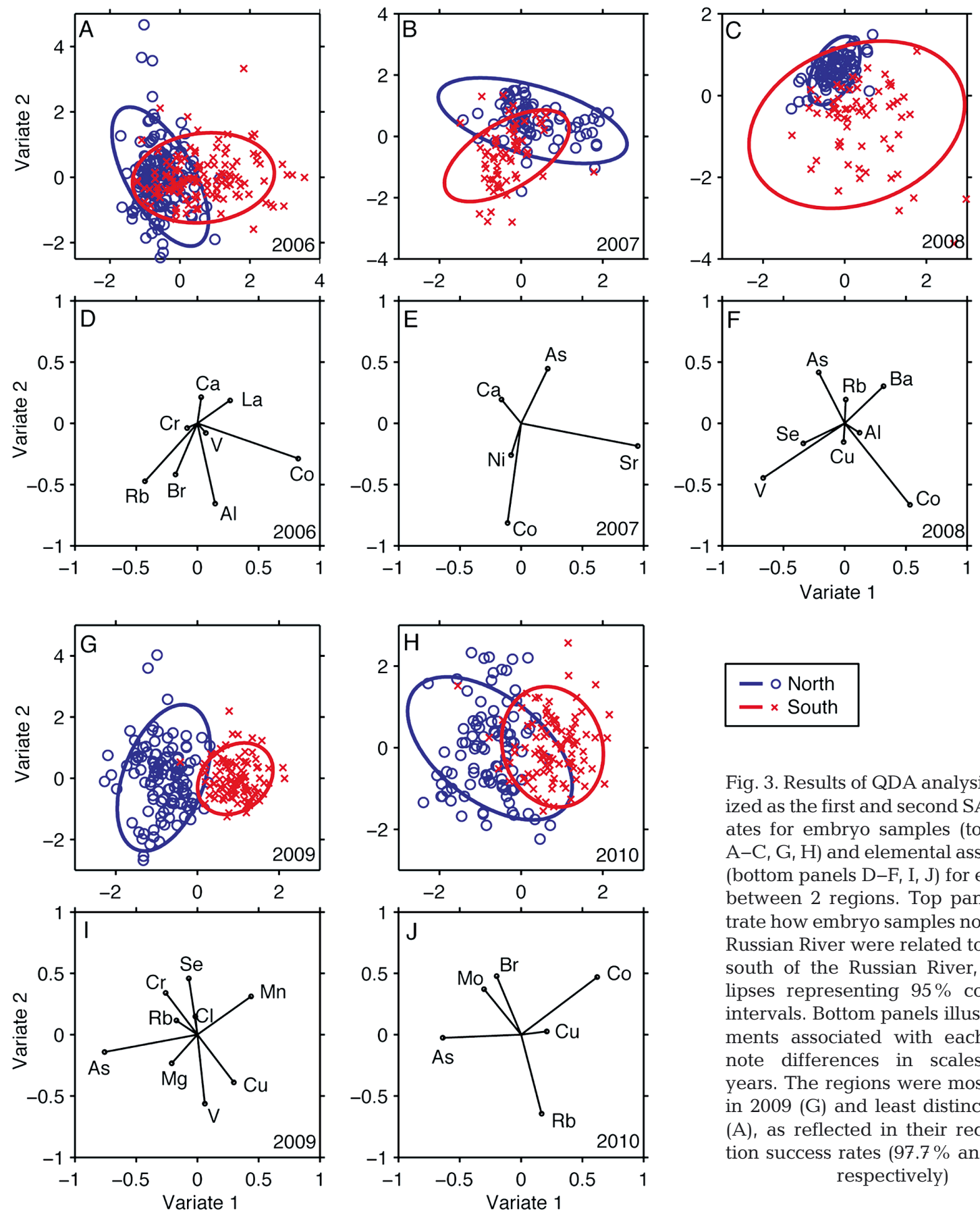

Fig. 3. Results of QDA analysis, visualized as the first and second SAVE variates for embryo samples (top panels A-C, G, H) and elemental associations (bottom panels D-F, I, J) for each year between 2 regions. Top panels illustrate how embryo samples north of the Russian River were related to samples south of the Russian River, with ellipses representing 95\% confidence intervals. Bottom panels illustrate elements associated with each region; note differences in scales among years. The regions were most distinct in 2009 (G) and least distinct in 2006 (A), as reflected in their reclassification success rates $(97.7 \%$ and $80.6 \%$, respectively)

searchers can improve the chances of success by investigating local features before the study begins. The relative importance of each of these features may vary by region, but understanding how among-site differences could affect the success of a natal atlas is critical to conducting a useful trace element study, particularly when funds are limited.

Different geological formations along the coastline may have contributed to spatial variation in embryo trace element signatures among sites. The distinctive geology at Arena Cove and Abalone Point, for example, could be important to the high reclassification success rates at those sites. In contrast to the Pleistocene-era terrace deposits along most of the northern California coast, the cobble field at Arena Cove is composed of Miocene-era marine sandstone and shale from the Monterey Group formation (Wagner \& Bortugno 1982), and the cobble at Abalone Point is Miocene-era Santa Cruz mudstone (Wagner et al. 1991). These different geologic deposits could likely 
Table 5. Percent correct reclassification results using each year's data (predictor year) to reclassify samples from other years (tested year). Results in bold are the highest success in each tested year, while italicized results represent success rates better than the null expectation of assignment by chance for that year (given in the bottom row of each section)

\begin{tabular}{|llllll|}
\hline \multirow{2}{*}{$\begin{array}{l}\text { Predictor } \\
\text { year }\end{array}$} & \multirow{5}{*}{2006} & 2007 & 2008 & 2009 & 2010 \\
\cline { 4 - 6 } Site & & & & & \\
2006 & $\mathbf{0 . 3 9 8 0}$ & 0.0429 & 0.0563 & 0.0682 & 0.0000 \\
2007 & 0.1024 & $\mathbf{0 . 4 3 2 6}$ & 0.1549 & 0.0682 & 0.0000 \\
2008 & 0.0683 & 0.1714 & $\mathbf{0 . 5 4 5 5}$ & 0.0682 & 0.0758 \\
2009 & 0.0512 & 0.0857 & 0.0845 & $\mathbf{0 . 5 4 3 0}$ & 0.0152 \\
2010 & 0.0733 & 0.0692 & 0.0226 & 0.0098 & $\mathbf{0 . 5 4 2 7}$ \\
Null & 0.0667 & 0.0667 & 0.0667 & 0.0455 & 0.0435 \\
Area & & & & & \\
2006 & $\mathbf{0 . 7 0 7 5}$ & 0.5571 & 0.5423 & 0.1318 & 0.1414 \\
2007 & 0.2355 & $\mathbf{0 . 7 5 1 8}$ & 0.6127 & 0.1318 & 0.1414 \\
2008 & 0.1365 & 0.5857 & $\mathbf{0 . 9 4 4 1}$ & 0.5318 & 0.1414 \\
2009 & 0.1365 & 0.1429 & 0.1408 & $\mathbf{0 . 9 4 5 7}$ & 0.2273 \\
2010 & 0.1365 & 0.1429 & 0.1408 & 0.2136 & $\mathbf{0 . 8 0 9 0}$ \\
Null & 0.3333 & 0.3333 & 0.3333 & 0.3333 & 0.3333 \\
Region & & & & & \\
2006 & $\mathbf{0 . 8 0 6 1}$ & 0.5571 & 0.5704 & 0.4682 & 0.4949 \\
2007 & 0.4846 & $\mathbf{0 . 8 2 9 8}$ & 0.5493 & 0.5318 & 0.5051 \\
2008 & 0.4881 & 0.5429 & $\mathbf{0 . 9 4 4 1}$ & 0.5318 & 0.4949 \\
2009 & 0.4539 & 0.4429 & 0.4577 & $\mathbf{0 . 9 7 7 4}$ & 0.3384 \\
2010 & 0.4539 & 0.4429 & 0.4577 & 0.6091 & $\mathbf{0 . 9 0 9 5}$ \\
Null & 0.5000 & 0.5000 & 0.5000 & 0.5000 & 0.5000 \\
\hline
\end{tabular}

increase the by-site reclassification success since rock types vary in their trace element signatures and their weathering could increase the likelihood that embryos from these sites have distinctive signatures (Klein \& Hurlbut 1993, Preda \& Cox 2001, Peng et al. 2004). Weathering of high- $\mathrm{CaCO}_{3}$ sandstone may have resulted in the higher than average calcium concentrations at 3 sites in 2007 (see Supplement 2 at www.int-res.com/articles/suppl/m474p179_supp. pdf; Klein \& Hurlbut 1993). Conversely, the consistently poor reclassification successes at some sites, such as Timber Cove and Shell Beach (Table 4), could have been due to the widespread occurrence of Pleistocene deposits, which likely created similar trace element signatures at these sites. The effect of variation in the elemental composition of rocks may be less pronounced for broadcast spawners because eggs are not closely associated with the substrate for long durations as the embryos of brooders are, though if trace element signatures are maternally transmitted, this caveat would be negated (Warner et al. 2005, Thorrold et al. 2006).

Variation in freshwater outflow can reduce the success of a natal site atlas by creating highly variable trace element signatures at some sites. For example, Bodega Harbor is a tidally flushed estuary that experiences negligible freshwater runoff during summer and fall but substantial runoff events during winter and spring. In particularly rainy winters, Petrolisthes cinctipes in Bodega Harbor is exposed to greater volumes of freshwater runoff as well as increased concentrations of pollutants, such as fertilizers, pesticides, herbicides, and automobile fluids (Smalling et al. 2010). Freshwater runoff and pollutants may strongly affect the trace element signature of water masses and embryos in Bodega Harbor in a wet year, such as 2006 (124.5 cm rainfall), whereas the signature would be more heavily influenced by the influx of seawater during a dry year, such as $2008(72.4 \mathrm{~cm}$ rainfall; data collected by the Bodega Ocean Observing Node at $38^{\circ} 19.110^{\prime} \mathrm{N}, 123^{\circ} 04.294^{\prime} \mathrm{W}$; http://bml. ucdavis.edu/boon/). Elements such as lead, zinc, and copper could be particularly variable because they have been shown to vary naturally among freshwater sources as well as with human influence (Table 1; Borrego et al. 2004, Hwang et al. 2009). This varying influence of trace elements from anthropogenic sources and naturally occurring in freshwater runoff could account for the high variability seen in the reclassification success of embryos from Bodega Harbor (25.0 to $73.3 \%$ correct; Table 4 ).

Consistent freshwater runoff, in contrast, can improve the success of a natal site atlas. The year-round outflow from San Francisco Bay may have generated the distinctive trace element signatures and high reclassification success at sites along the coast nearby, such as Abalone Point. Previous research has shown that all of the elements we sampled can vary among different freshwater sources due to natural and anthropogenic factors (Ouyang et al. 2006, Zeigler \& Whitledge 2011), creating particularly distinctive trace element signatures in areas influenced by freshwater runoff. The sites near San Francisco Bay experience terrestrially derived, anthropogenically influenced waters year-round, creating stability in the embryo trace element signatures, particularly of cobalt and copper, which are tracers of San Francisco Bay outflow (Hurst \& Bruland 2008).

The strong anthropogenic and terrestrial influences of freshwater runoff from San Francisco Bay appeared to be the most important feature in our study region in determining the reclassification success of areas (Flegal et al. 1991, 2005, Connor et al. 2007). When strong northwest winds periodically relax during the peak upwelling season, which coincides with the reproductive season for Petrolisthes cinctipes and many invertebrates in northern Califor- 
nia, outflow from San Francisco Bay flows around the tip of Point Reyes and northward along the coast (Wing et al. 1998). These anthropogenically influenced waters only occasionally flow north of the Russian River in Sonoma County, so the river makes a logical dividing line in our study region (Fig. 1). Thus, the area south of Point Reyes is heavily influenced by San Francisco Bay, the area between Point Reyes and the Russian River is periodically influenced by San Francisco Bay, and the area north of the Russian River is influenced by upwelled waters and their distinctive trace element signatures, rather than anthropogenic sources (Sanudo-Wilhelmy \& Flegal 1996). By dividing our study region into these 3 areas, we increased our reclassification success dramatically (Table 3 ). Dividing the study region using only the Russian River as the border further improved our success but provided substantially less detail for only modest gains in reclassification success. Therefore, grouping sites into 3 areas along the coast provided the highest reclassification success while retaining the most information, as found by Carson et al. (2008) for the same area.

Our high reclassification successes show that closely spaced sites along the open coast in a region of strong upwelling can have trace element signatures as distinctive as those found in studies that focused on widely spaced sites or included estuarine sites in their samples (e.g. Gillanders 2005, Warner et al. 2005, Becker et al. 2007, Standish et al. 2008). Features such as retention zones, upwelling centers, geologic formations, and riverine inputs combine to create a complex patchwork of trace elements along the open coast.

Despite the many challenges in creating a trace element atlas, our results indicate that judicious site selection can improve the usefulness of a natal site atlas. Nevertheless, the temporal instability of trace element signatures requires the atlas to be reconstructed each year, and interannual reclassification success rates will likely vary (Table 5). Using closely spaced sites along the open coast typically leads to some sites having mediocre reclassification success, making it necessary to combine sites into groups that cover larger geographical areas (see also Becker et al. 2005, Carson et al. 2008). However, the connectivity of populations among a few sites with distinctive signatures can still be distinguished even under these circumstances.

Based on our experience, we recommend considering the following criteria for creating a natal atlas to ensure the highest possible by-site (or by-group) reclassification success, though they should be used as a guide to include more useful sites rather than excluding sites that do not have distinctive features. After all, having many closely spaced sites improves estimates of population connectivity in a region. Taking measurements of how these criteria influence trace element signatures through time will also help researchers understand how important these criteria are in a specific study region.

- Geology. Study the local geologic map for differences in rock types that could lead to differences in local trace element concentrations.

- Habitat. If the study organism spans estuaries and the open coast, include sites with both habitats rather than just the most common habitat.

- Pollution. Incorporate sites that are highly polluted and others that are comparatively uncontaminated, though larvae from polluted sites might suffer higher mortality or delayed development.

- Runoff. Include sites with freshwater runoff and assess how interannual variability in freshwater runoff will influence trace element signatures.

- Local oceanography. Consider including sites where features like retention zones or upwelling centers might create distinctive trace element signatures.

Many factors should be considered when selecting sites for a study of population connectivity using trace element signatures. We have shown that it is possible to have high reclassification success at individual sites, even among multiple closely spaced sites on the open coast. Grouping sites when creating the natal site atlas can dramatically increase reclassification success, but it decreases the level of detail provided by the study. Therefore, it is preferable to include more groups in the atlas, even if the reclassification success is slightly lower than for fewer groups. Following the suggestions above when selecting sites will allow researchers to maintain a high level of detail in their study while achieving high reclassification success.

Our study also reveals the importance of considering scale when designing studies of population connectivity. Typically, researchers seek to match the spatial scale of the study to the spatial scale of the demographics or ecological interactions of the study organism (Wiens 1989, Levin 1992). When conducting a study using techniques such as trace elements that rely on factors that are variable over multiple scales, however, researchers must fit their study not only to the spatial scale of those factors but also to the spatial scale that is demographically relevant to the study organism. Researchers must therefore carefully match not only their study organisms but also 
their methodologies to the spatial scales over which both factors are relevant. Doing so will yield results that are meaningful and provide important and focused insights into how populations are connected through larval dispersal in coastal waters.

Acknowledgements. We thank C. Lord, S. Hameed, W. Dillon, and K. Nickols for help with field collections, M. Evans for laboratory assistance, and T. Young for ICP-MS availability. T. Hill, J. Largier, and C. Lord all improved the manuscript with their useful comments. This research was funded by California Sea Grant (NA08AR4170669) and the National Science Foundation (OCE-0326110). This publication is a contribution of the Bodega Marine Laboratory, University of California at Davis.

\section{LITERATURE CITED}

Almany GR, Berumen ML, Thorrold SR, Planes S, Jones GP (2007) Local replenishment of coral reef fish populations in a marine reserve. Science 316:742-744

> Anastasia JR, Morgan SG, Fisher NS (1998) Tagging crustacean larvae: assimilation and retention of trace elements. Limnol Oceanogr 43:362-368

> Anderson SL, Cherr GN, Morgan SG, Vines CA and others (2006) Integrating contaminant responses in indicator saltmarsh species. Mar Environ Res 62:S317-S321

Aruga R (1998) Closure of analytical chemical data and multivariate classification. Talanta 47:1053-1061

> Aruga R, Mirti P, Casoli A, Palla G (1999) Classification of ancient proteinaceous painting media by the joint use of pattern recognition and factor analysis on GC/MS data. Fresenius J Anal Chem 365:559-566

> Becker BJ, Fodrie FJ, McMillan PA, Levin LA (2005) Spatial and temporal variation in trace elemental fingerprints of mytilid mussel shells: a precursor to invertebrate larval tracking. Limnol Oceanogr 50:48-61

> Becker BJ, Levin LA, Fodrie FJ, McMillan PA (2007) Complex larval connectivity patterns among marine invertebrate populations. Proc Natl Acad Sci USA 104: 3267-3272

> Borrego J, Lopez-Gonzalez N, Carro B (2004) Geochemical signature as paleoenvironmental markers in Holocene sediments of the Tinto River estuary (Southwestern Spain). Estuar Coast Shelf Sci 61:631-641

Carlon DB, Olson RR (1993) Larval dispersal distance as an explanation for adult spatial pattern in two Caribbean reef corals. J Exp Mar Biol Ecol 173:247-263

Carson HS, Morgan SG, Green PG (2008) Fine-scale chemical fingerprinting of an open coast crustacean for the assessment of population connectivity. Mar Biol 153:327-335

Carson HS, Lopez-Duarte PC, Rasmussen L, Wang D, Levin LA (2010) Reproductive timing alters population connectivity in marine metapopulations. Curr Biol 20:1926-1931

> Chase Z, Johnson KS, Elrod VA, Plant JN, Fitzwater SE, Pickell L, Sakamoto CM (2005) Manganese and iron distributions off central California influenced by upwelling and shelf width. Mar Chem 95:235-254

Chiarenzelli J, Pominville C (2008) Bottled water selection and health considerations from multi-element analysis of products sold in New York state. J Water Health 6: 505-512
Connor MS, Davis JA, Leatherbarrow J, Greenfield BK and others (2007) The slow recovery of San Francisco Bay from the legacy of organochlorine pesticides. Environ Res 105:87-100

> Cook GS (2011) Changes in otolith microchemistry over a protracted spawning season influence assignment of natal origin. Mar Ecol Prog Ser 423:197-209

> DiBacco C, Levin LA (2000) Development and application of elemental fingerprinting to track the dispersal of marine invertebrate larvae. Limnol Oceanogr 45:871-880

Flegal AR, Smith GJ, Gill G, Sanudo-Wilhelmy SA, Anderson LCD (1991) Dissolved trace element cycles in the San Francisco Bay estuary. Mar Chem 36:329-363

Flegal AR, Conaway CH, Scelfo GM, Hibdon SA, SanudoWilhelmy SA (2005) A review of factors influencing measurements of decadal variations in metal contamination in San Francisco Bay, California. Ecotoxicology 14:645-660

- Fushimi A, Saitoh K, Fujitani Y, Hasegawa S, Takahashi K, Tanabe K, Kobayashi S (2011) Organic-rich nanoparticles (diameter: 10-30 nm) in diesel exhaust: fuel and oil contribution based on chemical composition. Atmos Environ 45:6326-6336

Gillanders BM (2005) Using elemental chemistry of fish otoliths to determine connectivity between estuarine and coastal habitats. Estuar Coast Shelf Sci 64:47-57

Graham WM, Largier JL (1997) Upwelling shadows as nearshore retention sites: the example of northern Monterey Bay. Cont Shelf Res 17:509-532

Hobbs JA, Bennett WA, Burton J, Gras M (2007) Classification of larval and adult delta smelt to nursery areas by use of trace elemental fingerprinting. Trans Am Fish Soc 136:518-527

> Hurst MP, Bruland KW (2008) The effects of the San Francisco Bay plume on trace metal and nutrient distributions in the Gulf of the Farallones. Geochim Cosmochim Acta 72:395-411

Hwang HM, Green PG, Young TM (2009) Historical trends of trace metals in a sediment core from a contaminated tidal salt marsh in San Francisco Bay. Environ Geochem Health 31:421-430

Jones GP, Milicich MJ, Emslie MJ, Lunow C (1999) Selfrecruitment in a coral reef fish population. Nature 402: 802-804

Kantarelou V, Ager FJ, Eugenidou D, Chaves F and others (2011) X-ray fluorescence analytical criteria to assess the fineness of ancient silver coins: application on Ptolemaic coinage. Spectrochim Acta B 66:681-690

Klein C, Hurlbut CS Jr (1993) Manual of mineralogy. John Wiley \& Sons, New York, NY

Korhoňová M, Hron K, Klimčíková D, Müller L, Bednář P, Barták P (2009) Coffee aroma-statistical analysis of compositional data. Talanta 80:710-715

> Lares ML, Flores-Munoz G, Lara-Lara R (2002) Temporal variability of bioavailable $\mathrm{Cd}, \mathrm{Hg}, \mathrm{Zn}, \mathrm{Mn}$ and $\mathrm{Al}$ in an upwelling regime. Environ Pollut 120:595-608

$>$ Levin SA (1992) The problem of pattern and scale in ecology: the Robert H. MacArthur award lecture. Ecology 73: 1943-1967

Levin LA, Huggett D, Myers P, Bridges T, Weaver J (1993) Rare-earth tagging methods for the study of larval dispersal by marine invertebrates. Limnol Oceanogr 38: 346-360

McKenzie ER, Money JE, Green PG, Young TM (2009) Metals associated with stormwater-relevant brake and tire samples. Sci Total Environ 407:5855-5860 
Miller SH (2011) Larval behavior and natural trace element signatures as indicators of crustacean population connectivity. $\mathrm{PhD}$ dissertation, University of California, Davis

Morgan SG, Fisher JL, Miller SH, McAfee ST, Largier JL (2009) Nearshore larval retention in a region of strong upwelling and recruitment limitation. Ecology 90: 3489-3502

> Neubauer P, Shima JS, Swearer SE (2010) Scale-dependent variability in Forsterygion lapillum hatchling otolith chemistry: implications and solutions for studies of population connectivity. Mar Ecol Prog Ser 415:263-274

$>$ Olson RR (1985) The consequences of short-distance larval dispersal in a sessile marine invertebrate. Ecology 66: 30-39

Ouyang TP, Zhu ZY, Kuang YQ, Huang NS and others (2006) Dissolved trace elements in river water: spatial distribution and the influencing factor, a study for the Pearl River delta economic zone, China. Environ Geol 49:733-742

Pardoe I, Yin X, Cook RD (2007) Graphical tools for quadratic discriminant analysis. Technometrics 49:172-183

Peng B, Song Z, Tu X, Xiao M, Wu F, Lv H (2004) Release of heavy metals during weathering of the Lower Cambrian black shales in western Hunan, China. Environ Geol 45: 1137-1147

Preda M, Cox ME (2001) Trace metals in acid sediments and waters, Pimpama catchment, southeast Queensland, Australia. Environ Geol 40:755-768

Sanchez-Garcia L, de Andres JR, Martin-Rubi JA (2010) Geochemical signature in off-shore sediments from the Gulf of Cadiz inner shelf: sources and spatial variability of major and trace elements. J Mar Syst 80:191-202

Sanudo-Wilhelmy SA, Flegal AR (1996) Trace metal concentrations in the surf zone and in coastal waters off Baja California, Mexico. Environ Sci Technol 30:1575-1580

Smalling KL, Morgan SG, Kuivila KK (2010) Accumulation of current-use and organochlorine pesticides in crab embryos from northern California, USA. Environ Toxicol Chem 29:2593-2599

Standish JD, Sheehy M, Warner RR (2008) Use of otolith natal elemental signatures as natural tags to evaluate connectivity among open-coast fish populations. Mar Ecol Prog Ser 356:259-268

Strathmann RR, Hughes TP, Kuris AM, Lindeman KC, Morgan SG, Pandolfi JM, Warner RR (2002) Evolution of local recruitment and its consequences for marine populations. Bull Mar Sci 70:377-396

Swearer SE, Shima JS, Hellberg ME, Thorrold SR and others (2002) Evidence of self-recruitment in demersal marine

Editorial responsibility: Inna Sokolova,

Charlotte, North Carolina, USA populations. Bull Mar Sci 70:251-271

Thorrold SR, Jones CM, Campana SE, McLaren JW, Lam JWH (1998) Trace element signatures in otoliths record natal river of juvenile American shad (Alosa sapidissima). Limnol Oceanogr 43:1826-1835

Thorrold SR, Jones GP, Hellberg ME, Burton RS and others (2002) Quantifying larval retention and connectivity in marine populations with artificial and natural markers. Bull Mar Sci 70:291-308

> Thorrold SR, Jones GP, Planes S, Hare JA (2006) Transgenerational marking of embryonic otoliths in marine fishes using barium stable isotopes. Can J Fish Aquat Sci 63: 1193-1197

Wagner DL, Bortugno EJ (1982) Geologic map of the Santa Rosa quadrangle, California. California Division of Mines and Geology, Sacramento, CA

Wagner DL, Bortugno EJ, McJunkin RD (1991) Geologic map of the San Francisco-San Jose quadrangle, California. California Division of Mines and Geology, Sacramento, CA

Warner RR, Swearer SE, Caselle JE, Sheehy M, Paradis G (2005) Natal trace-elemental signatures in the otoliths of an open-coast fish. Limnol Oceanogr 50:1529-1542

White JW, Ruttenberg BI (2007) Discriminant function analysis in marine ecology: some oversights and their solutions. Mar Ecol Prog Ser 329:301-305

White JW, Standish JD, Thorrold SR, Warner RR (2008) Markov chain Monte Carlo methods for assigning larvae to natal sites using natural geochemical tags. Ecol Appl 18:1901-1913

Wiens JA (1989) Spatial scaling in ecology. Funct Ecol 3: 385-398

> Wing SR, Largier JL, Botsford LW, Quinn JF (1995) Settlement and transport of benthic invertebrates in an intermittent upwelling region. Limnol Oceanogr 40:316-329

Wing SR, Botsford LW, Ralston SV, Largier JL (1998) Meroplanktonic distribution and circulation in a coastal retention zone of the northern California upwelling system. Limnol Oceanogr 43:1710-1721

- Wu L, Vomocil JA, Childs SW (1990) Pore size, particle size, aggregate size, and water retention. Soil Sci Soc Am J 54: 952-956

Z Zacherl DC (2005) Spatial and temporal variation in statolith and protoconch trace elements as natural tags to track larval dispersal. Mar Ecol Prog Ser 290:145-163

Zeigler JM, Whitledge GW (2011) Otolith trace element and stable isotopic compositions differentiate fishes from the Middle Mississippi River, its tributaries, and floodplain lakes. Hydrobiologia 661:289-302

Submitted: January 4, 2012; Accepted: October 12, 2012 Proofs received from author(s): January 22, 2013 